\title{
Cytotoxic and Antiproliferative Activities of Melia azedarach Leaves Ethanolic Extract on A549 Human Lung Cancer Cells
}

Author

Afiliation

\author{
Yusuf $\operatorname{Irshan}^{1}$, Irma H Suparto ${ }^{2,3}$, Sulistiyani ${ }^{1,4^{*}}$
}

${ }^{1}$ Department of Biochemistry, Bogor Agricultural University, Bogor, Indonesia
${ }_{2}^{2}$ Department of Chemistry, Bogor Agricultural University, Bogor, Indonesia
${ }^{3}$ Primate Research Center, Bogor Agricultural University, Bogor, Indonesia
${ }^{4}$ Biopharmaca Research Center, Bogor Agricultural University, Bogor, Indonesia

\section{Keyword}

O A549 human lung cancer cells

$\rightarrow$ Aantiproliferative activity

Cytotoxic activity

- Melia azedarach

Received 20 October 2015 Revised 25 September 2016 Accepted 23 March 2017

*Corresponding author Sulistiyani Department of Biochemistry, Bogor Agricultural University Email :

sulistyanisoemardi@gmail.com

\section{ABSTRACT}

Melia azedarach (Meliaceae) is known locally as mindi, gringging, renceh, or cakra-cikri is known to have pharmacological properties. The leaves contain flavonoids such as kaempferol and quercetin that have anticancer activity. The objective of this research is to evaluate the potency of Melia azedarach leaves ethanolic extract as anticancer by inhibition of cancer cell proliferation. Cytotoxic effect was analyzed by Brine Shrimp Lethality Test (BSLT) and cell viability (MTT) methods using Chang human normal liver cells and A549 human lung cancer cells. Antiproliferative effect of the extract was analyzed by cell direct calculation method using hemacytometer. The leaves were extracted with ethanol $96 \%$ by maceration method. Phytochemical investigation showed that the extract contains flavonoids, alkaloids, tannins, saponins, and steroids. Assay of BSLT showed that crude ethanolic extract of $M$. azedarach has a cytotoxic effect with $\mathrm{LC}_{50}$ value of $63.98 \mu \mathrm{g} / \mathrm{mL}$, which is an indication for very potential bioactive compund as anticancer. Consistent with BSLT assay, cell viability (MTT) assay showed that this extract was able to reduce cell viability with $\mathrm{IC}_{50}$ values of $299.22 \mu \mathrm{g} / \mathrm{mL}$ on Chang cells and $130.56 \mu \mathrm{g} / \mathrm{mL}$ on A549 cancer cells. As control, Curcuma zedoaria extract at $75 \mu \mathrm{g} / \mathrm{mL}$ reduced $\mathrm{A} 549$ cells viability to $38.8 \%$, which was equivalent to the effect of M. azedarach extract at $50 \mu \mathrm{g} / \mathrm{mL}$. These data suggest that Melia azedarach extract is potentially more bioactive than Curcuma zedoaria extract. This result is supported by the ability of the extract $(5 \mu \mathrm{g} / \mathrm{mL}$ ) to inhibit $A 549$ cells proliferation as much as $73.53 \%$.

\section{INTRODUCTION}

Cancer is a malignant tumor which is characterized by the abnormal body cells growth with the potential to invade or spread to other body parts (Vij et al. 2014). WHO (2014) reported that 8.2 million people worldwide died of cancer in 2012. Lung cancer ranked first about $19 \%$, followed by liver cancer $9 \%$, stomach cancer $8 \%$, colon cancer $7 \%$, and breast cancer $6 \%$. About $90-95 \%$ cases of cancer are caused by environmental factors and 5-10\% due to genetic factors. Environmental factors which could increase the risk of developing cancer are smoking, diet, alcohol, infections, radiation, stress, 
lack of physical activity, obesity, and pollutants (Anand et al. 2008).

One of the alternatives for cancer therapy is by utilizing the medicinal plants which have anticancer activities. Exploration of anticancer herbal with high effectiveness and minimum side effects need to be developed. One of the plants that potentially contains anticancer compounds is Melia azedarach (Pan et al. 2014). This plant is versatile because it can be used for various purposes including health remedy (Ahmed et al. 2012). The Chinese often use it as a raw material of traditional medicine for treatment of hypertension and anthelmintic (Asadujjaman et al. 2013). According to Azam et al. (2013) and Bhargava (2013), all parts of the plant which includes the root, bark, leaf, fruit, and seeds contain a variety of active compounds that are thought can be potential as cardioprotective, antioxidant, antimicrobial, antiulcer, analgesic, anticancer, antipyretic, antiplasmodial, and antiinflammatory.

Aoudia et al. (2013) reported that $M$. azedarach leaves ethanolic extract contained kaempferol and quercetin. Both of these compounds were the flavonoids that have anticancer activity (Kuldeep and Eisha 2014). These compounds prevented oxidative damage in the body's cells, lipids, and DNA that can increase the risk of developing cancer (Calderon et al. 2011). According to Cui et al. 2008, consumption of kaempferol was correlated with a decrease in the incidence of lung cancer of the smokers as well as nonsmokers. This compound inhibited the proliferation of lung cancer cells and caused naturally programmed cell death. Quercetin inhibited the proliferation of various cancer cell lines, one of which was A549 cells (Ren et al. 2003).

Although, M. azedarach leaves have been known to contain bioactive compounds, the scientific information on the benefits of $M$. azedarach leaves as anticancer is still limited. The objective of this research is to evaluate the in vitro potency of $M$. azedarach leaves extract as anticancer on human lung cancer cell lines. This paper reported the cytotoxic and antiproliferative activities of $M$. azedarach leaves extract on A549 human lung cancer cells.

\section{METHODS}

\section{Materials}

M. azedarach leaves were obtained from Biopharmaca Research Center, Bogor Agricultural
University, Bogor. Cysts of Artemia salina Leach $(A$. salina Leach) and sea water were obtained from Faculty of Fisher and Marine Science, Bogor Agricultural University. A549 human lung cancer cells (ATCC-CCL185) and Chang human normal liver cells (ATCC-CCL13) were obtained from ATCC (American Type Culture Collection). Curcuma zedoaria extract as positive control of cytotoxicity assay by viability (MTT) method were obtained from UD. Rachma Sari. DMSO, $\mathrm{NaHCO}_{3}$, trypsin, tripan blue, penicillin-streptomycin, FBS (fetal bovine serum), PBS (phosphate buffered saline), DMEM (Modifed Dulbecco's Eagle Medium), and tetrazolium (MTT) were obtained from Sigma Aldrich. The other materials were ethanol 96\%, methanol, $\mathrm{H}_{2} \mathrm{SO}_{4}, \mathrm{HCL}$, chloroform, ammonia, Dragendrof, Mayer, and Wagner reactans, acetic acid anhydride, $\mathrm{FeCl}_{3}$, diethyl ether, , aluminum foil, and Whatmann filter paper No. 1.

The tools which were used were oven, blender, micropipette, serological pipette, digital balance, rotary evaporator, water bath, spectrophotometer UV-Vis (Genesis 10v), lamp, aquarium, aerator, lup, BSLT plate, microplate 96 (Bio-Rad), plate 12 (Bio-Rad), Biosafety cabinet class II, sentrifuse (Flexpin), incubator $\mathrm{CO}_{2}$, flask, microplate reader (Bio-Rad), hemacytometer, and microscope (Nikon).

\section{Preparation of Extract (BPOM 2005)}

The leaves were collected, washed, and air-dried for seven days at room temperaturre. The dried leaves were stored in an oven at $40^{\circ} \mathrm{C}$ until the constant weight was obtained. Subsequently, the simplicia was made into powder using a blender. The powdered simplicia were extracted with ethanol $96 \%$ by maceration method in volume rasio of $1: 10(\mathrm{v} / \mathrm{v})$ for two days at room temperature. The filtrate was evaporated using a rotary evaporator at $50^{\circ} \mathrm{C}$.

\section{Phytochemical Assay (Seth and Sarin 2010)}

Flavonoids. $0.1 \mathrm{~g}$ of extract was mixed with $2 \mathrm{~mL}$ of methanol and was heated for 5 minutes at $80^{\circ} \mathrm{C}$. The filtrate was mixed with $0.01 \mathrm{~g}$ of $\mathrm{Mg} \cdot 3 \mathrm{H}_{2} \mathrm{O}$, and then mixed with $1 \mathrm{~mL}$ of $\mathrm{H}_{2} \mathrm{SO}_{4}$ and $1 \mathrm{~mL}$ of amylalcohol. The formation of red or orange colour on lining of amylalcohol showed the presence of flavonoids.

Alkaloids. $0.5 \mathrm{~g}$ of extract was mixed with $10 \mathrm{~mL}$ of chloroform and 2 drops of ammonia. Chloroform fraction was separated and acidified with $1 \mathrm{ml}$ of $\mathrm{H}_{2} \mathrm{SO}_{4}$. The fraction of $\mathrm{H}_{2} \mathrm{SO}_{4}$ was taken and added with

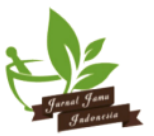


Dragendorf, Meyer, or Wagner reagent. Alkaloids presence was characterized by precipitates of the following colours: white by Meyer, red by Dragendorf, and brown by Wagner reagents.

Tannins. $0.1 \mathrm{~g}$ of extract was mixed with $5 \mathrm{~mL}$ of water, heated for 5 minutes at $80^{\circ} \mathrm{C}$, and then mixed with 3 drops of $\mathrm{FeCl}_{3}$. The formation of green indicated the presence of tannins.

Saponins. $0.1 \mathrm{~g}$ of extract was mixed with $5 \mathrm{~mL}$ of water, heated for 5 minutes at $80^{\circ} \mathrm{C}$, and then shaked until foamy. The existence of a stable foam for 15 minutes showed the presence of saponins.

Steroids and terpenoids. $0.5 \mathrm{~g}$ of extract mixed with $25 \mathrm{~mL}$ of ethanol, heated for 5 minutes at $80^{\circ} \mathrm{C}$, and then filtered. Filtrate was evaporated and mixed with $1 \mathrm{~mL}$ of diethyl ether. Diethyl eter layer was mixed with Lieberman-Buchard reagent. The formation of blue or green indicated the presence of steroids and red or purple indicated the presence of terpenoids.

\section{Brine Shrimp Lethality Test (BSLT) method (Syafii et al. 2014)}

Cysts of $A$. salina Leach were weighed about 50 $\mathrm{mg}$, put in an aerated container which contained sea water and then incubated for 48 hours under artificial light. Cysts of $A$. salina Leach were hatched into larva after 24 hours. Larva of 48 hours old $A$. salina Leach were used for this assay. About 10 of $A$. salina Leach larva were put into the vial containing sea water and extract were added in final concentrations of 9, 22.5, 45, 90, 180, $360 \mu \mathrm{g} / \mathrm{mL}$, and $0 \mu \mathrm{g} / \mathrm{mL}$ (control). Observation was made after 24 hours of incubation. The numbers of larva which lived were counted and expressed as \% mortality value using the formula:

$$
\% \text { Mortality }=\frac{\text { Lcontrol }- \text { Lsample }}{\text { Lcontrol }} \times 100 \%
$$

$L=$ The numbers of larva which lived

\section{Cell Culture (Doyle and Griffiths 1999)}

The growth medium was made by preparing DMEM powder in sterile bottles and adding $3.7 \mathrm{~g}$ of $\mathrm{NaHCO}_{3}$, penicillin-streptomycin $1 \%$, and FBS $10 \%$, homogenized and the volume was made into $1000 \mathrm{~mL}$ with double-distilled water. Chang human normal liver cells and A549 human lung cancer cells were grown using flask in DMEM growth medium until confluence in air/CO2 $(95 \% / 5 \%)$ incubator at $37^{\circ} \mathrm{C}$. The cells were subcultured using trypsination method. Briefly, the medium was discarded and rinsed with PBS solution, then $5 \mathrm{~mL}$ of trypsin was added and followed by incubation at $37 \mathrm{C}$ for 5 minutes. The reaction was stopped by addition of $4 \mathrm{~mL}$ medium. The suspension was centrifuged for 5 minutes at $700 \mathrm{~g}$. The supernatant was discarded and the pellet (cells) was mixed with $5 \mathrm{~mL}$ of medium. Subsequently, the number of cells were calculated using a hemocytometer; for cell viability assay 5000 cells/well were added each in 100 $\mu \mathrm{L}$ volume into a 96 well-microplate and 100,000 cells/well each in $2000 \mu \mathrm{L}$ volume into a 12 wellmicroplate for antiproliferative assay. All cell cultures were incubated for 24 hours in a $5 \% \mathrm{CO}_{2}$ incubator at $37^{\circ} \mathrm{C}$ before the experiment.

\section{Viability (MTT) Assay (CCRC 2009)}

In this assay, both Chang and A549 cells were incubated with or without extracts at final concentrations of: $0,510,15,25,50,100,250,500$, 800 , and $1000 \mu \mathrm{g} / \mathrm{mL}$ in total volume of $100 \mu \mathrm{L}$ each well. The Curcuma zedoaria extract was added at 75 $\mathrm{mg} / \mathrm{mL}$ as positive control. All cell cultures was incubated for 48 hours in a $5 \% \mathrm{CO}_{2}$ incubator at $37^{\circ} \mathrm{C}$. Subsequently, tetrazolium (MTT) $5 \mathrm{mg} / \mathrm{mL}$ was added in aliquots of $10 \mu \mathrm{L} /$ well which turned the cell medium into yellow colour. All cells were incubated for 4 hours in $5 \% \mathrm{CO}_{2}$ incubator at $37^{\circ} \mathrm{C}$. After incubation, the cell medium was discarded and $100 \mu \mathrm{l}$ of ethanol $96 \%$ were added into each wells. The absorbance values was measured using a spectrophotometer at $595 \mathrm{~nm}$ wavelength. The results were expressed as \% inhibition value using the formula:

$$
\begin{gathered}
\% \text { Inhibition } \\
A=\text { Absorbance }
\end{gathered}
$$

\section{Antiproliferative Assay (CCRC 2009)}

Following 24 hours incubation, medium of A549 cell cultures were discarded, and the cells were incubated with extract at concentration of $5 \mu \mathrm{g} / \mathrm{mL}$ (based on the results of cytotoxicity assay on Chang and A549 cells). This experiment was carried out for 24 , 48 , and 72 hours. At the end of experiment, the cells were harvested by trypsination method as mentioned earlier. The cell suspension was centrifuged for 5 minutes at $700 \mathrm{~g}$. The supernatant was discarded and the cell pellet was mixed with $5 \mathrm{~mL}$ of medium. The 
number of cells were calculated using a hemacytometer.

\section{Statistical Analysis}

Results are expressed as means of triplicate dishes at each point \pm SEM. Statistical significance was analyzed with one-way ANOVA.

\section{RESULTS AND DISCUSSION}

The M. azedarach leaves ethanolic extract yield was $26.96 \pm 0.12 \%$. Results on the qualitative analysis of phytochemical constituents of $M$. azedarach leaves extract were showed in Table 1 . The extract contained flavonoids, alkaloids, tannins, saponins, and steroids but did not contain terpenoids. One of the phytochemical constituents of plants which have been known as antiproliferative agent is flavonoids. Flavonoids is one of the kinds of polyphenols which was contained in plants (Doughari et al. 2009). Aoudia et al. (2013) reported flavonoids which contained in $M$. azedarach leaves ethanol extract were: kaempferol-3O- $\beta$-rutinosida, quercetin-3-O- $\beta$-D-glycoside, quercetin$C$, kaempferol-C, and rutin.

The BSLT cytotoxicity assay showed that the extract was cytotoxic with $\mathrm{LC}_{50}$ value of $63.98 \mu \mathrm{g} / \mathrm{mL}$ (Figure 1). This is an indication for very potential bioactive compund anticancer because of the very small LC $_{50}<1000 \mu \mathrm{g} / \mathrm{mL}$ (Mudi and Salisu 2009, Emrizal et al. 2014). This test was done as early screening for anticancer prior to in vitro assay using cell cultures (Oktaviani et al. 2013). Syafii et al. (2014) and Jafari et al. (2013) reported that BSLT test correlated with
Table 1. Phytochemical constituents of extract

\begin{tabular}{clc}
\hline No. & Constituents & Extract \\
\hline 1 & Flavonoids & + \\
2 & Alkaloids & + \\
3 & Tannins & + \\
4 & Saponins & + \\
5 & Steroids & + \\
6 & Terpenoids & - \\
\hline+ (The presence of phytochemical constituents) and \\
- (The absence of phytochemical constituents)
\end{tabular}

cytotoxic and antiproliferative activities on cell cultures. The lower $L C_{50}$ value of the extract, the higher the cytotoxicity and antiproliferative effects on cell cultures.

The cytotoxicity assay using cell viability (MTT) method is shown in Figure 2. The M. azedarach extract showed a cytotoxic effect on both normal Chang and cancer A549 cells at all concentrations Both types of cells decreased their viability upon incubation with this extract. The $\mathrm{IC}_{50}$ value of the extract were 299.22 $\mu \mathrm{g} / \mathrm{mL}$ on Chang cells and $130.56 \mu \mathrm{g} / \mathrm{mL}$ on A549 cells. This result shows that both type of cells are good cell model for bioactive potency of this extract. However, the A549 lung cancer cells were more susceptible than the Chang normal liver cells as showed by smaller $\mathrm{IC}_{50}$ value. The similar observation had been reported by Schnablegger (2010) on his study using some cancerous cell lines and normal peripheral blood monocytes. The susceptibility of the cancer cell lines to bioactive components was due to the higher proliferative activity.

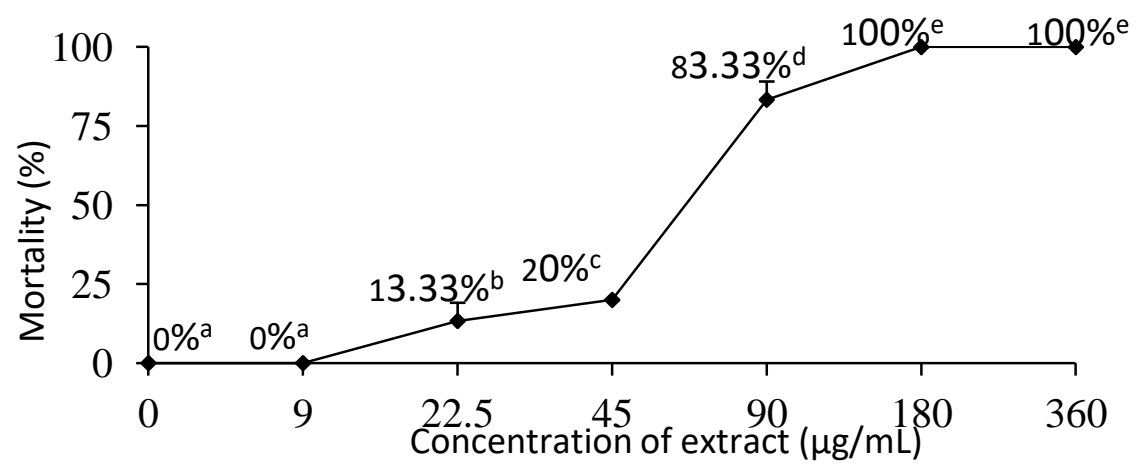

Figure 1. Result on the BSLT assay of extract. Asterisks illustrate statiscally significant differences between concentrations and mortality

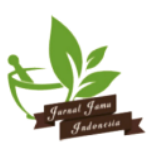


On the contrary, extract of C. zedoaria which served as positive control $(\mathrm{K}+)$ only bioactive to $\mathrm{A} 549$ cancer cells. At $75 \mu \mathrm{g} / \mathrm{mL}$, this extract reduced $\mathrm{A} 549$ cells viability to $38.78 \%$, which was equivalent to the effect of $M$. azedarach extract at $50 \mu \mathrm{g} / \mathrm{mL}$. These results suggested that $M$. azedarach extract was potentially more effective than $C$. zedoaria extract as anticancer. This is consistent with report by Lakshmi et al. (2011) on the effect of isolated isocurcumenol from Curcuma zedoaria rhizomes on human and murine cancer cells. Curcuma zedoaria was found to inhibit the cancer cells without inducing significant effect to the normal cells. This lack of bioactive effect on normal cells could be due to the absent of the mechanism(s) that were otherwise present only in cancer cells.

Figure 3 shows the results of antiproliferative assay. The extract at $5 \mu \mathrm{g} / \mathrm{mL}$ could inhibit A549 cells proliferation as much as $73.53 \%$ after 72 hour incubation. This inhibition was quite significant since it was caused by crude extract. The inhibition of A549 cells growth by mindi extract could be due to the flavonoids content of the extract which decreased the cell proliferation ability. Flavonoids extract from Gymnostemma pentaphyllum was reported to inhibit A549 cells proliferation by $92 \%$ (Tsui et al. 2014). They reported that flavonoids from Gymnostemma pentaphyllum inhibited A549 cells proliferation by cell cycle arrest and induction of apoptosis. Flavonoids

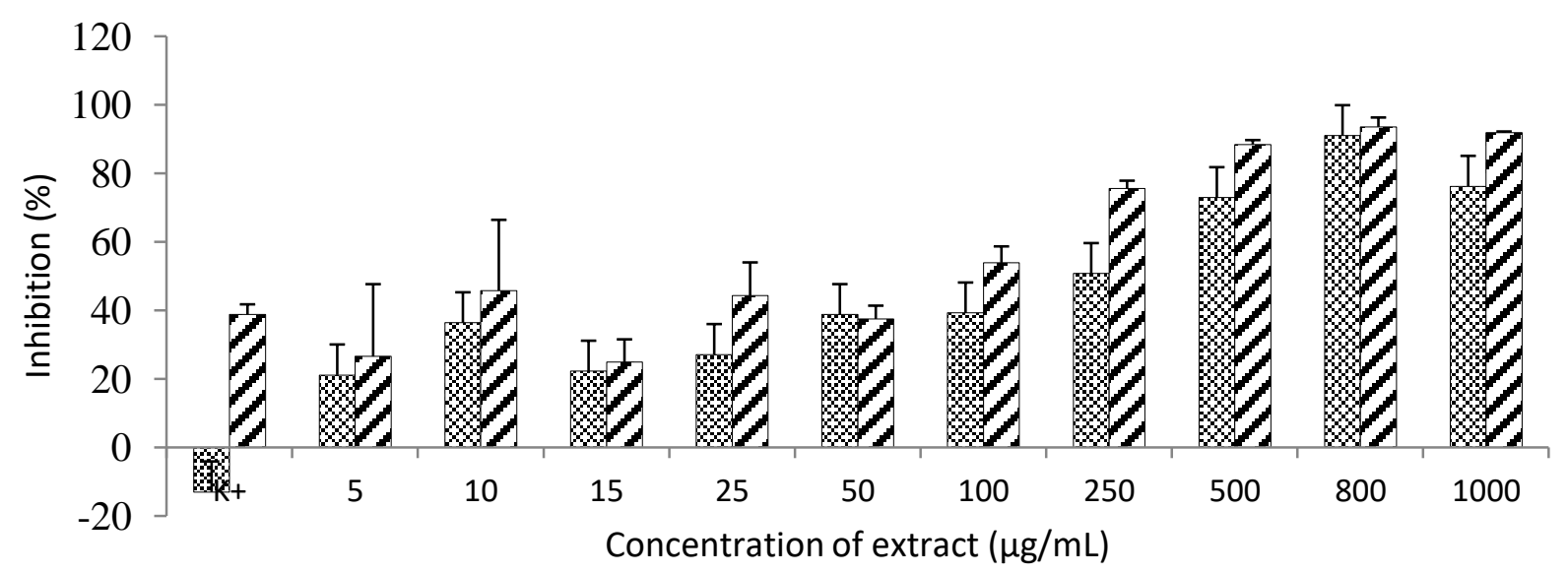

Chang cells $\square$ A549 cells

Figure 2. Result on MTT assay of extract on Chang and A549 cells viability. Asterisks illustrate statiscally significant differences between concentrations and inhibition activity

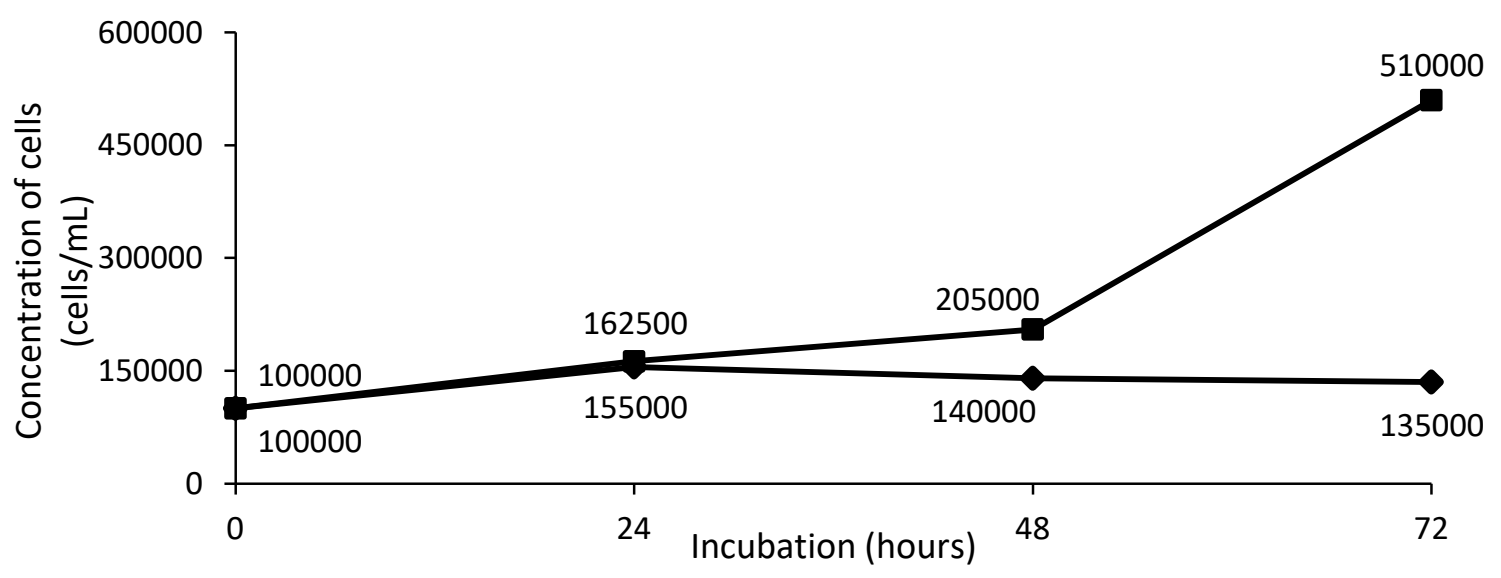

Figure 3. A549 cells proliferative cell $(\rightarrow)$ with extract of $5 \mu \mathrm{g} / \mathrm{mL}$ and $(\rightarrow-)$ without extract 


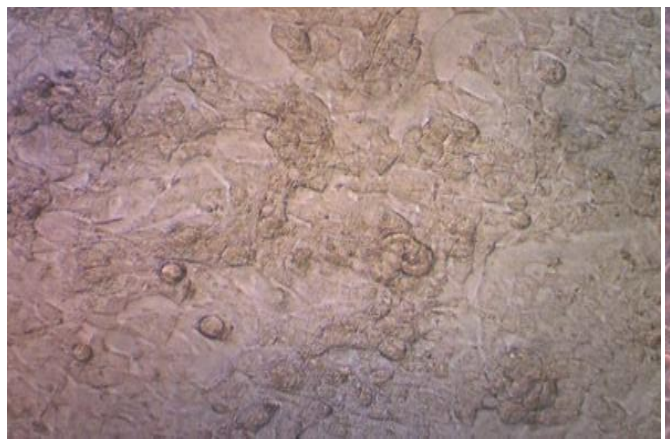

(a)

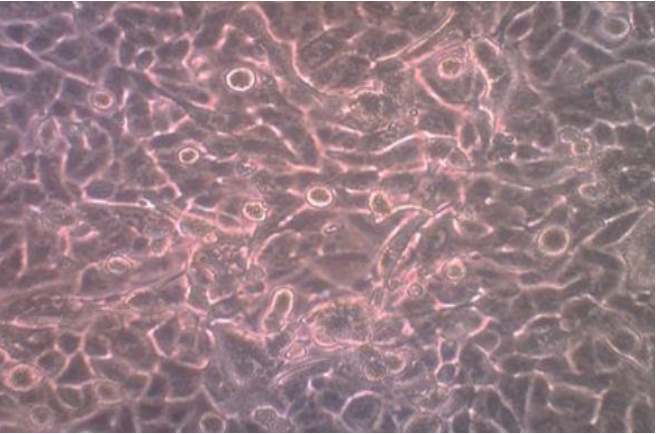

(b)

Figure 4. (a) A549 cells with extract at $5 \mu \mathrm{g} / \mathrm{mL}$ dan (b) A549 cells without any extract

inhibited the cyclin dependent kinase ( $\mathrm{Cdk})$ which is the regulator of the cell cycle (Rao et al. 2012). The action point of flavonoids were inhibition of CAK (CdkActivating Kinase) enzyme so inhibited the formation of Cyclin-Cdk complex. This caused a series of signal transduction to be stopped and the cell cycle was stopped at G1 phase (post-mitosis) or S phase (DNA synthesis) (Meiyanto and Septisetyani 2005).

The morphology of A549 cells with extract did not show a good shape and did not colonize (Figure 4a), while A549 cells without extract showed good cell shape and the cells grew in colony (Figure 4b). Faried et al. (2007) reported similar observation on the effect of gallic acid isolated from Phaleria macrocarpa (Scheff) on human cancer cell lines morphology. They reported that flavonoids induced apoptosis by reducing the regulation of antiapoptosis protein, like tyrosine kinase. Flavonoids inhibited the signal transduction process of growth factors by acting as a competitive inhibitor which prevented the phosphorylation of tyrosine kinase receptor (Lee et al. 2001). Inhibition of proliferation and induction of apoptosis also could be increased through the proapoptosis proteins regulation, like $B A X$ ( $B c l-2$-associated $X$ protein), BAD (Bcl-2-associated death promoter), BAK (Bcl-2 homologous antagonist killer), P21, P27, and P53 (Utami 2011, Tsui et al. 2014).

\section{CONCLUSION}

The result of the present study showed that the Melia azedarach leaves ethanolic extract is very potential bioactive compund as anticancer. Extract has a $\mathrm{LC}_{50}$ value of $63.98 \mu \mathrm{g} / \mathrm{mL}$ and $\mathrm{IC}_{50}$ values of 299.22 $\mu \mathrm{g} / \mathrm{mL}$ on Chang cells and $130.56 \mu \mathrm{g} / \mathrm{mL}$ on A549 cells.
M. azedarach extract was more effective compared to Curcuma zedoaria extract in inhibit cancer cells proliferation. Curcuma zedoaria extract at $75 \mu \mathrm{g} / \mathrm{mL}$ only reduce $A 549$ cells viability of $38.78 \%$, which is equivalent to $M$. azedarach extract at $50 \mu \mathrm{g} / \mathrm{mL}$. This is supported by antiproliferative assay which showed that extract at $5 \mu \mathrm{g} / \mathrm{mL}$ could inhibit A549 cells proliferation as much as $73.53 \%$.

\section{ACKNOWLEDGEMENTS}

This work was partially supported by a grant from Student Creativity Program (PKM) and 2014 IPB Desentralize Research Grant from Directorate General of Higher Education of the Indonesian Ministry of Cultural and Education. The authors thanks Ms. Silmi Mariya and lin Indriawati for technical assintance in cell cultures preparation.

\section{REFERENCES}

Ahmed MF, Rao AS, Ahmad SR, Ibrahim M. 2012. Phytochemical studies and antioxidant activity of Melia azedarach leaves by DPPH scavenging assay. International Journal of Pharmaceutical Applications. 3(1): 271-276.

Anand $P$, Kunnumakara $A B$, Sundaram $C$, Harikumar $K B$, Tharakan ST, Lai OS, Sung B, Aggarwal BB. 2008. Cancer is a preventable disease that requires major lifestyle changes. Pharmaceutical Research. 25(9): 2097-2116.

Aoudia H, Oomah BD, Zaidi F, Zaidi YR, Drover, Harrison. 2013. Phenolics, antioxidant, and antiinflammatory activities of Melia azedarach extracts. International Journal of Applied Research in Natural Products. 6(2): 19-29. 
Asadujjaman M, Saed A, Hossain M, Karmakar U. 2013. Assessment of bioactivities of ethanolic extract of Melia azedarach (Meliaceae) leaves. Journal of Coastal Life Medicine. 1(2): 118-122.

[ATCC] American Type Culture Collection. 2014. A549 (ATCC-CCL185). ATCC [internet]. [downloaded in 2014 September 22]. Available at: www.atcc.org/Products/All/CCL-185.

[ATCC] American Type Culture Collection. 2014. A549 (ATCC-CCL185). ATCC [internet]. [downloaded in 2014 September 22]. Available at: www.atcc.org/Products/All/CCL-13.

Azam MM, Mamun O, Towfique N, Sen M, Nasrin S. 2013. Pharmacological potentials of Melia azedarach L. - A review. American Journal of BioScience. 1(2): 44-49.

Bhargava S. 2013. Phytochemical screening and evaluation of its repellent activity of Melia azedarach L. Indo American Journal of Pharmaceutical Research. 2(3): 4310-4318.

[BPOM RI] Balai Penelitian Obat dan Makanan, Republik Indonesia. 2004. Fitofarmaka dan Obat Herbal Terstandar. Jakarta (ID): BPOM RI.

Calderon MJM, Burgos ME, Perez GC, Lopez LM. 2011. A review on the dietary flavonoid kaempferol. Mini-Reviews in Medicinal Chemistry. 11(4): 298 $-344$.

[CCRC] Cancer Chemoprevention Research Center. 2009. Prosedur Tetap Uji Sitotoksik Metode MTT. Yogyakarta (ID): Faculty of Pharmacy, Gadjah Mada University.

Cui Y, Morgenstern H, Greenland S, Tashkin DP, Mao JT, Cai L, Cozen W, Mack TM, Lu QY, Zhang ZF. 2008. Dietary flavonoid intake and lung cancer - a population based case control study. Cancer. 112(10): 2241-2248.

Doughari J, Human I, Bennade S, Ndakidemi. 2009. Phytochemicals as chemotherapeutic agents and antioxidants: possible solution to the control of antibiotic resistant verocytotoxin producing bacteria. Journal of Medicinal Plants Research. 3(11): 839-848.

Faried A, Kurnia D, Faried LS, Usman N, Miyazaki T, Kato H, Kuwano H. 2007. Anticancer effects of gallic acid isolated from Indonesian herbal medicine, Phaleria macrocarpa (Scheff.) Boerl, on human cancer cell lines. International Journal of Oncology. 30: 605-613.
Doyle A, Griffiths JB. 1999. Cell and Tissue Culture for Medical Research. New York (US): J Willey.

Emrizal, Fernando A, Yuliandari R, Rullah K, Indrayani NR, Susanty A, Yerti R, Ahmad F, Sirat HM, Arbain D. 2014. Cytotoxic activities of fractions and two isolated compounds from sirih merah (indonesian red betel), Piper crocatum Ruiz \& Pav. Procedia Chemistry. 13: 79-84.

Jafari S, Saeidnia S, Hajimehdipoor H, Ardekani MRS, Faramarzi MA, Hadjiakhoondi A, Khanavi M. 2013. Cytotoxic evaluation of Melia azedarach in comparison with Azadirachta indica and its phytochemical investigation. DARU Journal of Pharmaceutical Sciences. 21(37): 1-7.

Kuldeep G, Eisha G. 2014. Formulation and characterization of kaempferol nanoparticles. Asian Journal of Biomedical and Pharmaceutical Sciences. 4(34): 59-63.

Lakshmi S, Padmaja G, Remani P. 2011. Antitumour effects of isocurcumenol isolated from Curcuma zedoaria rhizomes on human and murine cancer cells. International Journal of Medicinal Chemistry. Article ID 253962: 1-13.

Lee CJ, Lee MH, Cho YY. 2014. Fibroblast and epidermal growth factors utilize different signaling pathways to induce anchorage-independent cell transformation in JB6 Cl41 mouse skin epidermal cells. Journal of Cancer Prevention. 19(3): 199208.

Meiyanto E, Septisetyani EP. 2005. Efek antiproliferatif dan apoptosis fraksi fenolik Ekstrak etanolik daun Gynura procumbens (Lour.) Merr. terhadap sel HeLa. Artocarpus. 5(2): 74-80.

Mudi SY, Salisu A. 2009. Studies on brine shrimp lethality and activity of stem bark extract of Acacia senegal on respiratory tract pathogenic bacteria. International Journal of Biomedical and Healthcare Science. 5(3): 139-143.

Octaviani CD, Lusiana $M$, Zuhrotun A, Diantini A, Subarnas A, Abdulah R. 2013. Anticancer properties of daily consumed vegetables Amaranthus spinosus, Ipomoea aquatica, Apium graveolens, and Manihot utilissimato LNCaP prostate cancer cell lines. Journal for Nurse Practitioners. 4 (1): 67-70.

Pan X, Matsumotoa M, Nishimoto $Y$, Ogihara E, Zhang J, Ukiyaa M, Tokudab H, Koikec, Akihisad, Akihisa. 2014. Cytotoxic and nitric oxide productioninhibitory activities of limonoids and other 
compounds from the leaves and bark of Melia azedarach. Chemistry \& Biodiversity. 11(8): 11211139.

Rao AS, Ahmed MF, Ibrahim M. 2012. Hepatoprotective activity of Melia azedarach leaf extract against simvastatin induced hepatotoxicity in rats. Journal of Applied Pharmaceutical Science. 2(7): 144-148

Ren W, Qiao Z, Wang H, Zhu L, Zhang L. 2003. Flavonoids: promising anticancer agents. Medicinal Research Reviews. 23(4): 519-534.

Schnablegger G. 2010. The anticancer activity of Cyathula prostata on two malignant cell lines. [thesis]. Port Elizabeth (ZA): Nelson Mandela Metropolitan University.

Seth R, Sarin R. 2010. Analysis of thephytochemical content ant anti-microbial activity of Jatropha gossypifolia L. Archives of Applied Science Research. 2(5): 285-291.

Syafii W, Sari RK, Maemunah S. 2014. Uji bioaktivitas zat ekstraktif pohon mindi (Melia azedarach) dengan metode Brine Shrimp Lethality Test. Jurnal Ilmu dan Teknologi Kayu Tropis. 12(1): 4855.

Tsui KC, Chiang TH, Wang JS, Lin LJ, Chao W, Chen B, Feng Lu J. 2014. Flavonoids from Gynostemma pentaphyllum exhibit differential induction of cell cycle arrest in $\mathrm{H} 460$ and A549 cancer cells. Molecules. 19(11): 17663-17681.

Utami D. 2011. Aktivitas antiproliferasi isolat 4 ekstrak petroleum eter daun Phaleria macrocarpa (Scheff.) Boerl. pada sel kanker serviks manusia (HeLa). Molekul. 6(2): 57-65.

Vij T, Prashar Y, Jain D. 2014. An updated review on cancer. International Journal of Production Research. 4(2): 91-102.

[WHO] World Health Organization. 2014. Cancer. WHO [internet]. [downloaded in 2014 Sept 22]. Available at: http://www.who.int/mediacentre/ factsheets/fs29. 